\title{
Immortality of the Soul in Ecclesiastes and Akan traditional Thought: A Comparative Analysis from an African Christian Theological Perspective
}

\author{
John Kwasi Fosu (iD) 1 \\ ${ }^{1}$ Ghana Baptist University College, Kumasi - Ghana.
}

\begin{abstract}
This article surveys the immortality of the soul in Ecclesiastes and Akan traditional thought from an African Christian theological perspective. Using comparative analysis, it argues that there is a remarkable similarity between the concept of immortality in Ecclesiastes and that of the Akan religio-cultural traditions. It is theologically significant to consider the immaterial nature of humankind, death and immortality that has been regarded as mystical and not experiential. This discovery of similarity with Ecclesiastes allows the Akan, and for that matter Africans, the possibility of relocating their religio-cultural and traditional worldviews within the wider context of the biblical cultures and thus Christian theology.
\end{abstract}

Correspondence: John Kwasi Fosu Email: revjkfosu@yahoo.com

Publication History Received 8th March, 2021, Accepted 6th April, 2021, Published online 12th April, 2021.

Keywords: Immortality, Worldview, Ecclesiastes, Akans

\section{INTRODUCTION}

Diverse cultural worldviews and traditions have attempted to answer the question of the immortality of the soul. ${ }^{1}$ Nevertheless, researchers are often confronted with the questions relating to life after death within scholarship: Do we survive death? Which components of man endures after death? Do beliefs about life after death reconcile with the modern worldview? These questions have been examined from different academic disciplines such as in theology, anthropology, psychology, sociology and fiction and arriving at diverse and often conflicting conclusions. ${ }^{2}$ There is, therefore, the need to examine the biblical literature on the subject especially as it engages the contemporary reader. For relevant theological formulations and hermeneutical reflections in recent times are culturally and contextually conditioned. ${ }^{3}$ In the light of this background, this paper reflects on the thought of immortality in Ecclesiastes from an African Christian theological perspective. ${ }^{4}$ It examines the concept of immortality as reflected on by the author of Ecclesiastes in comparison with the Akan worldview. ${ }^{5}$ The rationale for studying the notion of the immortality of the

\footnotetext{
Webb Stephen, "Immortality," in All the Wonder that Would Be: Exploring Past Notions of the Future, Science and Fiction (Cham, Springer, 2017), 265-296. https://doi.org/10.1007/978-3-319-51759-9_10

2 In addition to the theological discourse on the search for the prospect of human immortality, Michael J. Cholbi, The Science of Immortality (Pomona: John Templeton Foundation, 2018), 4 has drawn our attention to the fact that the subject has been approached from the perspective of philosophy and art, comparative anthropologgy, psychology, and social history and often with controversial conclusions. In the observation of Peter Kwasi Sarpong, theoretical reflections about death appears to have no point since those who have direct experience of death do not come back to narrate it. The Asantes express this difficulty beautifully when they say, obiara mfo owno atwedej na cnsan mma (no one climbs the ladder of death and returns). See Peter Kwasi Sarpong, Ghana in Retrospect: Some Aspects of Ghanaian Culture (Accra: Ghana Publishing, 1974), 21.

3 A. Wati Longchar, "Teaching Third World Contextual Theologies from Ecumenical Perspective - Tribal/Indigenous People's Theology," IJT 44, no. 1-2 (2002): 9.

4 Erich Zenger and Christian Frevel discussing the relevance of wisdom literature observe that "Für Christliche Existenz heute könnten die ersttestamentlichen Weisheitsüberlieferungen wichtige Anstöße und Hilfen geben" (The Old Testament wisdom traditions provide an important support and impetus for Christian existence- personal translation). See their work, "Die Bücher der Weisheit," in Einleitung in das Alte Testamnent, ed. Christian Frevel, et al (Stuttgart: W. Kohlhammer, 2012), 413.

5 One of the issues and the belief systems at the time of the writer of Ecclesiastes was the belief about immortality. There is thus the need to look at the author's reflections in relation to the point of view of the Akans of Ghana and among Asantes to be precise. Roland E. Murphy and Elizabeth Huwiler, New International Biblical Commentary: Proverbs, Ecclessiastes, Song of Songs (Peabody, MA: Hendrickson Publishers, 1999) 174. See also Zenger and Frevel, "Die Bücher der Weisheit," 413.
} 
soul in the book Ecclesiastes lies in the fact that, as one of the wisdom literature books, Ecclesiastes identifies an author who happens to stand within the tradition of his day and questions some of its answers. ${ }^{6}$ One of such is what the author developed as part of his main reflections which is about the issue of life after death or immortality.

Methodologically, this paper employs a comparative approach through a review of essential secondary literature on the subject. Following Pickvance, the comparative analysis seeks to explain and gain a better understanding of the causal processes involved in the creation of an event, feature, or relationship usually by bringing together variations in the explanatory variable or variables. ${ }^{7}$ As a methodological approach, the main thrust of comparative research is an "explanation of differences and the explanation of similarities." ${ }^{\prime 8}$ This study thus follows the comparative methodological procedure as proposed by Oliver Freiberger, in his Considering Comparison: A Method for Religious Studies ${ }^{9}$ and his article, "Elements of a Comparative Methodology in the Study of Religion." ${ }^{10}$ Following the comparative processes of Freiberg, four essential elements applied in this write-up include selection, description, juxtaposition and prescription. Under the selection, the concept of immortality as a metaphysical and theological concept is presented. With reference to the description, an attempt is hereby made to examine the notion of the immortality of the soul both in the thought of the author of Ecclesiastes (designated in this paper as Qohelet ${ }^{11}$ ) and that of the Akan traditional thought. This will lead to the section of juxtaposition. Under this element, the continuities and discontinuities will be reflected upon. Last but not the least, before a conclusion is drawn, the prescription element followed in this paper is presented as an implication from the analysis. Accordingly, critical reflections are done from an African Christian intercultural perspective. This approach has to do with theological reflections that engage the African culture, worldview and religious realities. It is contextual as all relevant theological formulations are. ${ }^{12}$ It thus seeks to reflect upon and express the Christian faith in African-thought-forms as it is experienced in African Christian communities, in dialogue with the Judeo-Christian Scripture and the rest of Christendom. ${ }^{13}$

In what follows, an attempt is made to explain the concept of immortality. This will lead to a brief survey of the book of Ecclesiastes and that of the Akans on their teachings about immortality. A critical reflection about the continuities and discontinuities will then be presented to include its implication for contemporary Christian theology and hermeneutics.

\section{What is Immortality?}

The Random House College Dictionary defines immortality as an "immortal condition or quality; unending life."14 From a philosophical perspective, William Reese has rightly noted that the phrase "of the soul" normally follows the term to denote "the infinitely prolonged existence of that center of awareness to which the term "I" refers." 15 The term "immortality of the soul" has been historically oriented toward a value of idealism, dualism and pluralism and not a materialistic system since, in the opinion of Reese, the soul or self is therein interpreted as a product of bodily functioning. ${ }^{16}$ Thus the notion of the immortality of the soul is historically rooted in the ancient Greek philosophical thoughts of Socrates, Aristotle and Stoicism, ${ }^{17}$ rationalized by Rene Descartes ${ }^{18}$ and advanced by Immanuel Kant. ${ }^{19}$

\footnotetext{
This is in line with Zenger and Frevel and Murphy's insightful argument that although Ecclesiastes maintains its traditional value, it is particularly appropriate for our current cultural situation. See their work, "Die Bücher der Weisheit," 413.

7 Chris Pickvance, "The four Varieties of Comparative Analysis: The Case of Environmental Regulation," Journal of Housing and the Built Environment 16 (2005): 7-28.

8 Reza Azarian, "Potentials and limitations of comparative method in social science," International Journal of Humanities and Social Science 1, no. 4 (2011): $113-125$.

9 Oliver Freiberger, Considering Comparison: A Method for Religious Studies (New York: Oxford University Press Inc, 2019).

10 Oliver Freiberger, "Elements of a Comparative Methodology in the Study of Religion," Religions 9, no. 9, no. 38 (2018).

11 The word Qohelet is used to refer to the author of Ecclessiastics within Old Testament Scholarship. Ludger Schwienborst-Schönberger explains that the name Kohelet (Qohelet) appears seven times in the book of Ecclesiastes. In the first chapter, the word is used as a proper noun and later in chapter 12, it is however used as appellative because it is used with an article. Orginally, the word was used in a feminine participle sense denoting a function and an office and later it was used as a masculine proper noun. Thus, the word Qohelet traditionally denotes function. See his article, "Das Buch Kohelet" in Einleitung in das Alte Testamnent, edited by Christian Frevel, et al. (Stuttgart: W. Kohlhammer, 2012), 472. See also, Robert V. McCabe, "The Message of Ecclesiastes," DBSJ 1, no. 1 (Spring 1996): 85.

12 Walter Hollenweger observes that, “All theologies are contextually conditioned." See "Intercultural Theology, Intercultural Theology - Theology Today 43, no. 1 (1986): 28-35, http://ttj.sagepub.com-/content/43/1/28.full.pdf. Accessed February 8, 2017.

13 John Kwasi Fosu, "The Phenomenon of Akan Witchcraft (Bayie) in Ghana: Critical Observations," in Hexerei-Anschuldigungen in weltweiter Perspektive Witchcraft accusations in global perspective, ed. Werner Kahl, Gabriele Lademann-Priemer (Hamburg, Germany: Missionshilfe Verlag), 169.

14 Jess Stein, ed., "Immortality" in The Random House College Dictionary, Revised Edition (New York: Random House, Inc., 1975 ), 667.

15 William L. Reese, "Immortality" in Dictionary of Philosophy and Religion: Eastern and Western Thought (Atlantic Highlands, New Jersey: Humanity Press, 1980), 247.

16 Reese, "Immortality," 248

17 It is worthy of note that, all these philosophers in one way or the other explained the notion of the Immortality of the soul as the soul surviving physical death although with minor differences in explanation. Socrates presented a number of proofs of immortality by asserting that "the center of our beings, and the locus of personality and intelligence, is an immortal soul" and that the tending and strengthening of which is our chief business in life. Stoicism allowed affirmation of partial immortality. See Reese, "Immortality," 248; 538.

18 According to Descartes, both the mind and matter survive their separation at death. Reese, "Immortality," 126.

19 Reese, "Immortality," 278, Kant affirmed immortality of the soul by arguing that the idea of immortality is the postulate of "Practical Reason."
} 
From the biblical point of view, the Old Testament lacks a distinct term for immortality although Proverbs 12:28 has the coinage "not-death" ('al-mawet). This means "in the way of righteousness is (eternal) life; the threading of her path is not death (immortality)."

The Hebrew word nephesh (literally means soul), which is often translated as "life" describes the non-material aspect of mind, emotions and will in human personhood that results from the union of spirit and body. From this understanding, the soul along with the human spirit will continue to live (possess immortality) when an individual physically dies. The nephesh is closely connected to one's inner personhood that it is usually used as a synonym for a "person" (Example, Lev 4:2; 7:20; Josh 20:3). In Ecclesiastes 4: 8; 6:2, Nephesh is used of humankind (man) as exercising certain authority or performing certain acts. ${ }^{20}$

The New Testament Greek terminologies that express the idea of immortality include $\dot{\alpha} \theta \alpha v \alpha \sigma i \alpha$ (deathlessness), $\ddot{\alpha} \varphi \theta \alpha \rho \tau \sigma \varsigma$ (incorruptible) and $\dot{\alpha} \varphi \theta \alpha \rho \sigma i \alpha$ (incorruptibility) in 1 Cor 15:52-54. From these terms, immortality denotes immunity from any kind of decay and death (the negative aspect) that comes from having or sharing the eternal divine life (the positive aspect). ${ }^{21}$

In a collocative sense, Paul's use of the Greek, $\dot{\alpha} \varphi \theta \alpha \rho \sigma i \alpha$ and $\dot{\alpha} \theta \alpha v \alpha \sigma i \alpha$ in 1 Cor 15:52-54 describes the immortality of the soul employing clothing imagery. Paul uses this metaphor to provide a concrete picture of the transformation mystery by which a mortal, corruptible body changes to an immortal, incorruptible body. ${ }^{22}$ In this context, therefore, $\dot{\alpha} \varphi \theta \alpha \rho \sigma i \alpha$ and $\dot{\alpha} \theta \alpha v \alpha \sigma i \alpha$ pertain to that which cannot wear out and corroborate the aspect of body denoting a form that is incapable of degeneration. Used in Romans 12:7, $\dot{\alpha} \varphi \theta \alpha \rho \sigma i \alpha$ means "no-corruption" (unable to experience deterioration); incorruptibility (not perishable). These words carry the sense of lacking the very capacity to decay or constitutionally break down. Here, Paul uses $\dot{\alpha} \varphi \theta \alpha \rho \sigma i \alpha$ among other things as a virtue which the Romans were to seek for, the result of which is eternal life.

Christian theologians on one hand, especially up to the medieval period, have defended the soul's immortality in the Platonic sense of immortal subsistence. ${ }^{23}$ In the first place, being immaterial and indivisible by nature, the soul is independent of the body and indestructible. Secondly, only a future life can bring to the necessary fruition about the capacities and endowment of human nature and can rectify present inequalities and injustices; and thirdly, the intrinsic, universal and persistent belief of humankind that there is life after death argues for its reality. ${ }^{24}$

On the other hand, some theologians such as Karl Barth, in his Die Kirchliche Dogmatik III/2: Die Lehre von der Schöffung argues against the theological notion of the immortality of the soul by positing that the human life is finite and that the notion of immortality or afterlife is a dream of Paganism. ${ }^{25}$

God alone is conceived as an immortal Being (1 Tim 6:16; Rom 1:23). This is because God alone has within Godself inexhaustible springs of life and energy and that decay and death are foreign to God's experience. ${ }^{26}$ Thus the use of the concept "immortality," from a theological perspective, denotes the survival of the soul or the immaterial part of humankind, after bodily death. It is the assertion that physical death does not end all of life in that the soul survives. ${ }^{27}$

\section{The Notion of Immortality in Ecclesiastes}

The need to reflect on the book of Ecclesiastes with particular reference to its theological anthropology has been acknowledged in recent scholarship. ${ }^{28}$ Affinities have been established between Ecclesiastes and both biblical and NonIsraelites' Wisdom Texts. Ecclesiastes fits within the wisdom body of the Old Testament along with Proverbs and Job should one excludes that of the apocryphal/ deuteron-canonical books. To this, Ecclesiastes forms part of the Wisdom books that contain observations and interpretations of human life and behaviour along with advice on how to live.

Regarding Ecclesiastes and non-Israelites' wisdom texts, most scholars have observed that biblical wisdom has affinities with other ancient Near Eastern societies. To Murphy, Ecclesiastes most strongly resembles texts from

\footnotetext{
20 Richard Pleijel, “To Be or to Have a nephesh? Gen 2:7 and the Irresistible Tide of Monism,” ZAW 131, no. 2 (2019): 198. https://doi.org/10.1515/zaw-20192007. Accessed April 7, 2021.

21 Murray J. Harris, "Immortality" in New Dictionary of Theology, ed. S. B. Ferguson and D. F. Wright, (Leicester: Inter-Varsity Press, 1988 ), 332.

22 Anthony C. Thiselton, The First Epistle to the Corinthians: A Commentary on the Greek Text (Grand Rapids: William B. Eerdmans Publishing Company, 2000), 1297.

23 Harris, "Immortality," 333; Samuele Bacchiocchi, Popular Beliefs: Are they Biblical? (Berrien Springs, MI: Biblical Perspectives, 2008), 69 has also observed that, "historically popular Christian thought has been deeply influenced by the dualistic teachings of Socrates and Plato, which were promoted in modified forms by Tertullian, Origen, Augustine, and Thomas Aquinas."

24 Murray J. Harris, “The New Testament View of Life After death,” Themelios 11, no. 2 (January 1986): 47-52 follows the perspective of R. L. Patterson, Plato on Immortality (University of Pennsylvania: University Park, Pennsylvania, 1965); Erwin Rohde, Psych: The Cult of Souls and Belief in Immortality among the Greeks (Kegan: London, 1925, 8th edn); Andrew S. Pringle Pattison, The Idea of Immortality (Clarendon: Oxford, 1922); Clifford H. Moore, Ancient Beliefs in the Immortality of the Soul (Harrap: London, 1931) that "The view of immortality that predominates in Western and Christian thought is Platonic, according to which the term signifies an inherent characteristic of every rational soul that guarantees its persistence after death."

25 Karl Barth, Die Kirchliche Dogmatik III/2: Die Lehre von der Schöffung (Zollikon-Zürich: Evang. Verl, 1948), 714-715.

26 Harris, "Immortality," 332

27 The synonymous expressions include "a future life," a "future state" and a "hereafter."

28 Murphy and Huwiler New International Biblical Commentary, 174. See also Schwienborst-Schönberger, "Das Buch Kohelet,” 473.
} 
Egypt and Mesopotamia, although no text matches it precisely in either genre or content. The first influence of these non-biblical texts to talk about is that of Mesopotamia. For instance, a Mesopotamian poem, "I will praise the Lord of Wisdom," from around 1100 B.C.E. laments the impossibility of knowing how to please one's god. Further, Murphy posits that perhaps the most striking parallel comes in the context of Gigamesh's grief over the death of his friend Enkidu and his fears that he may be mortal, that the alewife Siduri advises him by trying to deflect the hero's quest for immortality with words of reality. Most scholars have compared this Epic of Gilgamesh to the wisdom of Qohelet in Ecclesiastes 9:7-10. Concerning Qohelet's relationship with Greek tradition, most scholars are of the consensus that Ecclesiastes belongs to the Greek-influenced worldview. ${ }^{29}$

With particular reference to Qohelet's teaching on death and immortality, there have been two main opposing views concerning the actual intent of Qohelet's teaching on Eccl 3:11-21, 9:2-10, 12:7. These are the views on the immortal soul and the non-immortal soul. The idea of the Immortal Soul is that every human body houses an immortal soul that continues after death. Here, when one dies, only the material part of the body goes back to dust, but the soul lives on. ${ }^{30}$ Although different religions disagree with each other about where the soul goes after death, Qohelet, however, writes in Eccl 12:7 that the spirit (representing the immaterial component of humankind) returns to God, the giver of life. ${ }^{31}$ Before Eccl 12:7, Qohelet had noted that God set eternity in the heart of humankind; but without the ability to find out what God has done from the beginning to the end (Eccl. 3:11). In this case, the writer imagines that there is more to life than he or anyone else can figure out. God has planted in the human mind the notion of eternity, a reality that transcends human finiteness, yet God has not equipped humans to grasp it. Because man is unable to transcend his limits, Qohelet counsels his readers, as a result, to enjoy the good things God's creation has to offer.

The Non-Immortal Soul view contends that the word "soul" applies to the entire person. When God first created Adam in Paradise, He "breathed into his nostrils the breath of life, and man became a living soul" (Gen 2:7). Thus, man doesn't have a separate soul, but rather he is a soul. ${ }^{32}$ After man sinned, his entire person, or soul, became mortal and subject to death. According to this view, when a person dies, that person returns to the dust, and "the breath of life" returns to God interpreting the "breathe" in Eccl 12:7 as not being a conscious entity, but rather as a spark of life that exists in everything alive. At death, the sinner is truly dead - unconscious, asleep, waiting for the resurrection. This view is sometimes called "soul sleep." Proponents of this view refer to Eccl 9:5 to argue that the dead lie unconscious, asleep in their graves, awaiting the resurrection and that whether saint or sinner there is no work, or "knowledge or wisdom in the grave where you are going" (Eccl 9:10). ${ }^{33}$

It could be argued that, in the thoughts of Qohelet, there is some amount of reality about immortality although it is not clear in his mind, especially concerning the actual destiny of the soul after death. An examination of Eccl 9:4-6 (contra the proponents of non-immortality view) that identifies the contrast between the dead lion and the living dog ( $\mathrm{v}$ 4) supplies the meaning for verse 5 . This, therefore, weakens the teaching about the non-existence of the departed soul. The context, in agreement with the Expositor's Bible Commentary, suggests the ability to plan and work. ${ }^{34}$ To this, it is most probable that Qohelet was influenced by the Epic of Gigamesh's grief over the death of his friend Enkidu. ${ }^{35}$ For although there is a theological difference between the worlds of the Epic of Gilgamesh and that of Qohelet, the literary link between the two strongly supports this perspective. Moreover, the Epic of Gilgamesh challenges people to enjoy life but holds out no lasting source of hope. Similarly, Qohelet calls back to joy after each successive disillusionment thereby maintaining the paradox as central to human experience. Further, the living is aware that death is inevitable but from a human perspective, the dead are not told what the future holds for them. In this case, it could be argued that Qohelet is not teaching soul-sleep. Instead, the emphasis is on the contrast between the carnal knowledge of the living and the oppressed. ${ }^{36}$ Qohelet's reflection on the destinies of the constituent components of human life after death in Eccl 12:6-7 further strengthens his belief in life after death.

\footnotetext{
${ }_{29}$ Murphy and Huwiler, New International Biblical Commentary 162-170; Ludger Schwienborst-Schönberger, "Das Buch Kohelet" in Einleitung in das Alte Testamnent, edited by Christian Frevel, et al. (Stuttgart: W. Kohlhammer, 2012), 472-473. Leander E. Keck, et. al. eds. The New Interpreter's Bible: General Articles \& Introduction, Commentary, \& and Reflections for each Book of the Bible including the Apocryphal Books in Twelve Volumes, Volume V. (Nashville: Abingdon Press, 1997),273; James B. Pritchard, ed. The Ancient Near East: An Anthology of Texts and pictures (Princeton: Princeton University Press, 1958), 64.

30 Bacchiocchi, Popular Beliefs: Are they Biblical? 100-102 thinks that scholars who are in favour of the immortal soul view are mostly Catholics and most Protestants who are being influenced by the Platonic dualistic view. He comes to this conclusion after having traced the history of the belief in the immortality of the soul by focusing first on the impact of the Greek philosophers Socrates (470-399 B. C.), Plato (427-347 B. C.), and Aristotle (384-322 B. C.) on the development of the Christian understanding of human nature, and considering the key role played by Tertullian (155-240), Origen (ca. 185-254), Augustine (354-430) and Thomas Aquinas (1225-1274) in leading the church to adopt the Platonic dualistic view of human nature.

31 Murphy and Huwiler, New International Biblical Commentary, 162.

32 Donald A Carson et. al eds. New Bible Commentary: 21 $1^{\text {st }}$ Century Edition ( Leicester: Intervarsity Press, 1994$), 618$.

33 With reference to Eccl. 9:5-6, Bacchiocchi, Popular Beliefs: Are they Biblical? 102 for instance posits that the main argument here is that death puts an abrupt end to all activity "under the sun," and what follows death is sheol, the realm of the dead where there is a state of inactivity, without knowledge or consciousness.

34 Keck, et. al eds. The New Interpreter's Bible Commentary in 12 vols, vol 5, 311.

35 Pritchard, ed. The Ancient Near East: An Anthology of Texts and pictures, 64.

36 Kenneth L. Barker \& John R. Kohlenberger III. The Expositor's Bible Commentary: Old Testament, Abridged Edition. (Grand Rapids: Zondervan, 1994$), 1019$.
} 


\section{The Notion of Immortality in Traditional Akan Thought}

The Akans ${ }^{37}$ believe that reality cannot be limited to human reason alone. To Ajei, imagination, intuition and experience and feelings are also modes of knowing. ${ }^{38}$ In this case, it can be said that this forms part of the reasons why the expression of African cultural reality has been through art, music, folksong and myths rather than through logical analysis. Thus the Akan postulates reality that existence comprises visible and invisible realms such that there are things that really exist and yet are imperceptible. This is a way of saying that matter and spirit are understood as inseparable. ${ }^{39}$

Akans believe that the human person is a tripartite being with three inseparable components of which two are spiritual (immaterial) and one biological. ${ }^{40}$ These are mogya (blood) from the mother, ntor $כ$ (patrilineal spirit) from the father, and $\mathrm{kkra}$ (soul) from Onyame. Emmanuel Asante has insightfully noted that Akan's tripartite belief about human nature establishes three sets of bonds namely the blood or the maternal bond, the spirit or the paternal bond and the soul or the theological bond. ${ }^{41}$

The soulbond is what Asante refers to as the God-human bond. This concerns the relationship existing between the individual Akan and that of the Supreme deity who is known as Onyame. Here the Akans believe that a person has Jkra (soul) that comes directly from Onyame (God). Kwame Gyekye also describes the concept of the Jkra in Akan thought as having a reservoir of strength and sustenance and states that the Jkra is considered to be that which constitutes the very innermost self, the essence, of the individual person. The $\mathrm{Jkra}$ is the individual's life and so it is referred to as כkrateasefos (the living soul). It is thus divine and has an ante-mundane existence with God. The כkra, therefore, might be considered as the equivalent of the concept of soul in other metaphysical systems. ${ }^{42}$

Gyekye further notes that the source of the person's energy which is $ə k r a$ is linked closely with another concept known as honhom. Honhom here means "breath" being derived from the Akan verb home (to breathe). It is the cessation of this breathe that the Akan sees as the one being passed away. Similarly, Asante points out that, it is the linkage of the skra with the honour, or the breath of a person that expresses the Akan's belief in Onyame as a giver of the Akan's soul. ${ }^{43}$ Thus the human person is non-alive without this $\mathrm{skra}$ element that comes directly from Onyame.

Besides, the $\mathrm{kra}$ is also connected with a person's nkrabea (destiny or manner of being). With this concept, the Akans believe that before a child is born, he enjoys pre-worldly existence and comes with a message that prescribes what the child is to become and to do in the world. Thus, for the Akan, the human person has a God-given project to carry out here in the world. This implies an obligation because every individual has a purpose in that there is God-given destiny that includes God-given projects to be carried out in the world. ${ }^{44}$

With particular reference to the Akan concept of immortality, when a person dies, the Akans say, ne honhom $k \supset$ (his soul is gone) or ne kra afi neho (his soul has withdrawn from his body). In these two expressions, honhom and Jkra express the same thing, as the death of the person. Gyekye expresses that the departure of the soul from the body

\footnotetext{
37 The ethnic name "Akan" refers to the Twi - speaking people of the Coast of Guinea of West Africa. The Akans consists of Ahanta, Akuampim, Akyem or Akim, Agus or Anyio, Asante or Ashanti, Asen or Asin, Bono or Brong, Busa, Chorkosi, Fante, Guan, Kwahu, Nzema and Wasa. Geographically, the Akan inhabit the Eastern part of Cote D' Ivoire, the Southern half and part of the North of Ghana and the north of Togoland. The culture and religion of the Akans exhibit a fairly uniform pattern in spite of the fact that they consist of many autonomous subgroups, the common language, and social institution link them together. See Emmanuel Asante, Towards an African Christian Theology of the Kingdom of God: The Kingship of Onyame (Gueenston: The Edwen Mellen Press, 1995), 73.

38 Ajei uses the Akan terms nea wohu, nea etra adwen and nea wonhu to explain the traditional Akan modes of knowing in Akan epistemology. See his work, Martion O. Ajei, The Paranormal: An Inquiry into Some Features of an African Metaphysics and Epistemology. (Hamburg: Missionshilfe Verlag, 2014), 6971.

39 Ajei has questioned the legitmacy of postulating dualistic view of the universe in Akan ontology by arguing that the Akan thinker conceives of these two realms as two points of continuum; Ajei, The Paranormal, 36-37.

40 Kwame Gyekye, An Essay on African Philosophical Though: The Akan Conceptual Scheme (Cambridge: Cambridge University Press, 1987$)$, 72-73.

41 Most African philosophical and anthropological accounts suggest that the Akan considers the human person as metaphysically constituent of $\supset k r a$ (usually translated into English as soul), the sunsum (the activating principle in the person) and Honam (the body). The relationship of Jkra to sunsum has, however, occasioned a philosophical debate which still rages on and has produced different positions on the matter. Whereas Ghanaian Philosophers such as Gyekye, Kofi Opoku Asare and Kwasi Sarpong see the sunsum as an ontological unity with the skra to be exclusively spiritual, Wiredu and Kwame Sarfro have argued for a quasi-physical nature of Sunsum. See also John Kwasi Fosu, Experiences of pneumatic phenomena in contemporary Ghanaian Christianity as appropriations of 1. Cor 12-14: A Critical Analysis (Hamburg: Missionshilfe Verlag, 2019), 179-190 for a detailed submission on the Akan thoughts on sunsum. See also Kwame Safro, "Quasi-Materialism: A Contemporary African Philosophy of Mind," in A Companion to African Philosophy, ed. Kwasi Wiredu (Oxford: Blackwell, 2004), 343-351; Kofi Asare Opoku, West African Traditional Religion (Accra: F. E. P. International Private Limited, 1978), 94-95; and Gyekye, An Essay on African Philosophical Thought: 93-96; 103. Kwasi Wiredu, "The Akan Concept of Mind" Ibandan Journal of Humanistic Studies, 3, (1983): 113-134.

42 Gyekye, An Essay on An Essay on African Philosophical Thought, 85.

43 Kwame Gyekye, "The Akan Concept of a Person" in Africa Philosophy: An introduction, $3^{\text {rd }}$ edition, ed. Richard A Wright (Lonham, M.D: University Press of America, 1984), 201.

44 Asante, Towards an African Christian Theology of the Kingdom of God, 79.
} 
means the death of the person. ${ }^{45}$ According to Gyekye, it is the Jkra that ceases the breathing making the honhom form part of the tangible manifestation or evidence of the כkra. The departure of the honhom from the body evinces the soul's departure from the body to enjoy post-mundane existence with Onyame. What this means is that the $J k r a$ is undying. ${ }^{46}$ Here, Kwame Gyekye explains that:

Traditional African Religions hold the common belief that the soul is an immaterial part of the human being that survives death and that humans, in an afterlife will give an account to God for their life in this world. Ideas about the soul held by the African people are highly elaborate and complex. Some say the human soul consists of four parts, others say three parts and others say two. What appears to be common to the various ideas about the soul, however, is that the soul is some spark of God in human person- making it of divine origin- and that the soul of human person is held to be immortal. ${ }^{47}$

From the above explanation, it can be said that the presence of this divine essence in humans may be the basis of the Akan maxim: All humans are the children of God; no one is a child of the earth. Gyekye further explains that this divine essence also makes every human person unique, of intrinsic value, and an end in himself or herself. This means that he or she should not be used as a means to an end. Also, the belief that the soul of a person survives bodily death is expressed in the Akan maxim: When a person dies, he is not (really) dead. Hence, there is something in human beings that continues to exist in another world which is "the world of the spirits." 48

Moreover, an Akan artistic symbol, assuming the immortality of God, expresses that: Onyame wu a na mawu (Could God die, I will also). This means that since God will not die, a person's soul that is considered as an indwelling spark of God will not die either. In other words, the eternity of God implies the immortality of the human soul which is part of the divine essence. Thus, in the traditional Akan thought, the world of spirits inhabited by those who have departed this life is based upon these assumptions about the immortality of the human soul and personal survival in an afterlife. ${ }^{49}$

\section{Continuities and discontinuities between Qohelet's and Akan's concept of immortality: A critical reflection}

The background studies on Ecclesiastes indicate that most probably, Qohelet derived information through observations, sayings, instructions and stories in the form of epics from his immediate environment. This is very much similar to that of the Akan who also have proverbs that are collected through observations and life experiences, symbols and stories. Reflections on the concept of immortality in the view of Qohelet in comparison with the traditional Akan thoughts on the subject identify some continuities and discontinuities.

To begin with the continuities, the Akan understanding of the immortality of the soul that has to do with the immaterial component of a person in generally keeping with the notions of immortality preserved in certain traditions of the Old Testament, and apparently in the cultural context of Qohelet. Qohelet asserts that the spirit of man returns to the creator after death (Eccl. 12:7). Thus, both Akan and Qohelet's thoughts affirm that there is life after death and that this life after death is associated with the soul (the immaterial aspect) of the person.

Moreover, Qohelet's reflection that God has put eternity in the heart of man and that God alone has eternity within Godself most probably implies that there is a fellowship of God with the souls of the person after death. This, therefore, corresponds to the Akan belief that the soul, after death, goes to be with the Supreme Being, the giver of life, thereby creating a sacred community. Further, the concept of immortality as theologically designated to God alone, as implied in the thought of Qohelet, in a sense underscores the Akan maxim that Onyame wu a, na ma wu (if God dies,

\footnotetext{
Interestingly, Gyekye, An Essay on African Philosophical Thoughts, 76 has attempted to reduce the beings of the Akan ontology into two categories: the spiritual and the physical. He, however, accords ontological priority to the spiritual by asserting that beings in the spiritual realm can have causal influence on bodies but not vice versa. On the other hand, Wiredu advocates a physical monism for Akan ontology by reducing all the entities postulated in this ontology to materiality. See also Kwasi Wiredu, "The Concept of Mind with particular reference to Language and Thoughts of the Akans," in Contemporay Philosophy: A New Survey, Vol 5 (Dredcht: Martinus Nijhoff Publishers, 1987), 160-163. One has a good reason, however, to speak of a number of beings in Akan ontology which belong to the realm of neither dualism nor material monism. This is because whereas in the Akan ontological scheme God (Onyame) is, beyond doubt, a spirit in the Cartesian sense, it is not at all clear whether many other beings have that status: the abosom (deities), the human being, and others belong exclusively to either a spiritual realm or a physical realm. It could be said that these existences partake of the features of both ontological categories.

46 Gyekye, "The Akan concept of a Person;" in Africa Philosophy: An Introduction, 201.

47 Asante, Towards an African Christian Theology of the Kingdom of God, 79.

48 Kwame Gyekye, African Cultural Values: An Introduction (Accra: Sankofa Publishing Company, 1996), 13-14

49 Joseph W. Acheampong, "I will pass over you: The Relevance of the Passover to the Understanding of Salvation in Contemporary Ghanaian Pentecostalism - A Critical Reflection from an Akan Perspective" (Dr. Theologie diss., Universität Hamburg, 2015), 51-144, has recently drawn attention to the final destinations of all the immaterial components of the humankind in traditional Akan thought. He writes that, "death is the point of exit of a person from this life (or the physical world) into the world of the spirits. At death, the physical component of the human person (or the body) is kept in the 'womb' of Asase Yaa or (mother earth). The part which connects a person to Nyame, the okra (or soul) departs to Nyame, where it will be judged. The sunsum (or the spirit) turns into saman (or a ghost) and, if the person qualifies as an ancestor, the saman will join the ancestors at asamando (or the other world). If the person does not qualify to be an ancestor, his/her saman wanders in the physical world as a 'wild ghost' or saman twentwen. As an ancestor, the dead person remains a part of the family, even though not in a physical sense. He/she assumes a stronger and a higher position as an intermediary between Nyame and those in the physical world."
} 
I will also) giving the idea that God alone is indeed immortal. This view about immortality then confirms the Akan traditional thought that the Supreme Being is the eternal Father of all.

Regarding what appears to be discontinuities, about the Akan teaching that the dead (especially the righteous dead who are thought to have attained the status of ancestors) form part of the living and thereby offering assistance to the living, Qohelet expresses that the dead do not know their future and for that matter about the living in offering guidance of whatever kind (Eccl. 9:5-6). Qohelet's teaching that the dead know nothing may not be an assertion that the dead are asleep. Rather it implies that the dead have no contact with this world. Thus, immortality understood in this sense (Eccl. 9:6-7) should therefore allow for a constructive dialogue between the religio-cultural traditions of the Akan and the Bible, for that matter Christianity.

\section{Implications from the analysis}

The comparative analysis on the notion of the immortality of the soul between the thought of Qohelet and that of the traditional Akan thought juxtaposed above in the form of continuities and discontinuities presents some contextual hermeneutical implications. Interpreting and reflecting on the Judeo-Christian Scripture especially on the hereafter must not be done with a view of alienating the traditional Akan and for that matter the contemporary reader from their religio-cultural traditions. When this is done, deep understanding would be attained, most importantly, in terms of its intercultural enrichment. And what has been said about the Akan in this article, for instance, can to some extent be said concerning other indigenous African readers since their religio-cultural traditions share common characteristics and concerns..$^{50}$

\section{CONCLUSION}

This study has been an attempt to look at the notion of immortality in the view of the writer of Ecclesiastes and that of the traditional Akan thought. It has been found out that the concept of the immortality of the human soul identified in Qohelet's thoughts finds similar understanding in the Akan religio-cultural traditions. This discovery of similarity of thoughts allows the Akan, and for that matter Africans, the possibility of relocating their religio-cultural and traditional worldviews within the wider context of the biblical cultures and thus Christian theology. In this case, the acknowledgment and acceptance of the continuities in these worldviews regarding the prospect of human immortality make contextual and intercultural reading of Scripture meaningful.

\section{ABOUT AUTHOR}

Rev. Dr. John Kwasi Fosu is a Lecturer at the School of Theology and Ministry of the Ghana Baptist University College,Kumasi, Ghana.

\section{BIBLIOGRAPHY}

Acheampong, Joseph W."I will pass over you: The Relevance of the Passover to the Understanding of Salvation in Contemporary Ghanaian Pentecostalism - A Critical Reflection from an Akan Perspective.” PhD Diss., Universität Hamburg, 2015.

Ajei, Martin O. The Paranormal: An Inquiry into Some Features of an African Metaphysics and Epistemology. Hamburg: Missionshilfe Verlag, 2014.

Asante, Emmanuel. Towards an African Christian Theology of the Kingdom of God: The Kingship of Onyame. Gueenston: The Edwen Mellen Press, 1995.

Azarian, Reza. "Potentials and limitations of comparative method in social science." International Journal of Humanities and Social Science 1, no. 4 (2011): 113-125.

Bacchiocchi, Samuele. Popular Beliefs: Are they Biblical? Berrien Spring, MI.: Biblical Perspectives, 2008.

Barker Kenneth L. \& Kohlenberger III John R. The Expositor's Bible Commentary: Old Testament, Abridged Edition. Grand Rapids: Zondervan, 1994.

Barth, Karl. Die Kirchliche Dogmatik III/2 Die Lehre von der Schöffung. Zollikon-Zürich: Evang. Verl, 1948. Carson, Donald A. et. al eds. New Bible Commentary: $21^{\text {st }}$ Century Edition. Leicester: Intervarsity Press, 1994.

Cholbi, Michael J. The Science of Immortality. Pomona: John Templeton Foundation, 2018.

Fosu, John K., Experiences of Pneumatic Phenomena in Contemporary Ghanaian Christianity as Appropriations of 1. Cor 12 - 14: A Critical Analysis. Hamburg: Missionshilfe Verlag, 2019.

. "The Phenomenon of Akan Witcheraft (Bayie) in Ghana: Critical Observations." In Hexerei-Anschuldigungen in weltweiter Perspektive Witchcraft accusations in global perspective. Edited by Werner Kahl, Gabriele

50 John S. Mbiti, African Religions and Philosophy: 2 $2^{\text {nd }}$ ed. (USA: Heinemann Educational Complex, 1969), $155-159$. 
Lademann-Priemer, 167-186. Hamburg: Missionshilfe Verlag, 2020.

Freiberger, Oliver. Considering Comparison: A Method for Religious Studies. New York: Oxford University Press Inc, 2019.

Gyekye, Kwame. African Cultural Values: An Introduction. Accra: Sankofa Publishing Company, 1996.

"The Akan Concept of a Person." In Africa Philosophy: An Introduction, the $3^{\text {rd }}$ Edition, edited by Richard A

Wright. Lanham: University Press of America, 1984.

. An Essay on African Philosophical Thought: The Akan Conceptual Scheme Rev. ed. Philadelphia: Temple University Press, 1995.

Harris, Murray. J. “Immortality.” In New Dictionary of Theology, edited by Ferguson, S. B. and Wright, D. F. Leicester: Inter-Varsity Press, 1988.

" "The New Testament View of Life After death." Themelios 11, no. 2 (January 1986): 47-52.

Hollenweger, Walter. "Intercultural Theology." Intercultural Theology - Theology Today 43, no. 1 (1986): 28-35. http:// ttj.sagepub.com/content/43/1/28.full.pdf.

Keck, Leander E., et. al. eds. The New Interpreter's Bible: General Articles \& Introduction, Commentary, \& and Reflections for each Book of the Bible including the Apocryphal Books in Twelve Volumes, Volume V. Nashville: Abingdon Press, 1997.

Longchar, A. W. "Teaching Third World Contextual Theologies from Ecumenical Perspective- Tribal/Indigenous People's Theology." IJT 44, no. 1\&2 (2002): 9-19

Mbiti, John S. African Religions and Philosophy, $2^{\text {nd }}$ ed. USA: Heinemann Educational Complex, 1969.

McCabe, Robert V. “The Message of Ecclesiastes.” DBSJ 1 (Spring 1996): 85-112.

Moore, Clifford H. Ancient Beliefs in the Immortality of the Soul. London: Harrap Publishing Group Ltd., 1931.

Murphy, Roland E. and Huwiler, E. New International Biblical Commentary: Proverbs, Ecclesiastes, Song of Songs. Peabody, Massachusetts: Hendrickson Publishers, 1999.

Opoku, Kofi A. West African Traditional Religion. Accra: F. E. P. International Private Limited, 1978.

Patterson, Robert L. Plato on Immortality. University of Pennsylvania: University Park, Pennsylvania, 1965.

Pattison, Andrew S. P. The Idea of Immortality. Clarendon: Oxford, 1922.

Pickvance, Chris. "The Four Varieties of Comparative Analysis: The Case of Environmental Regulation." Journal of Housing and the Built Environment 16 (2005): 7-28.

Pleijel, Richard. "To Be or to Have a nephesh? Gen 2:7 and the Irresistible Tide of Monism." ZAW 131, no. 2 (2019: 194-206. https://doi.org/10.1515/zaw-2019-2007

Pritchard, James B., ed. The Ancient Near East: An Anthology of Texts and Pictures. Princeton: Princeton University Press, 1958.

Reese, William L. "Immortality.” In Dictionary of Philosophy and Religion: Eastern and Western Thought. Atlantic Highlands, NJ: Humanity Press, 1980.

Rohde, Erwin. Psych: The Cult of Souls and Belief in Immortality among the Greeks, $8^{\text {th }}$ Edition. London: Kegan, 1925.

Safro, Kwame. "Quasi-Materialism: A Contemporary African Philosophy of Mind." In A Companion to African Philosophy, edited by Kwasi Wiredu. Oxford: Blackwell, 2004.

Sarpong, Peter. Ghana in Retrospect: Some Aspects of Ghanaian Culture. Accra - Tema: Ghana Publishing Corporation, 1974.

Schwienborst-Schönberger, Ludger. "Das Buch Kohelet." In Einleitung in das Alte Testamnent, edited by Christian Frevel, et al. Stuttgart: W. Kohlhammer, 2012.

Stein, Jess, Chief, ed. "Immortality.” In The Random House College Dictionary, Revised Edition. New York: Random House, Inc., 1975.

Thiselton, Anthony C. The First Epistle to the Corinthians: A Commentary on The Greek Text. Grand Rapids: William B. Eerdmans Publishing Company, 2000.

Webb, Stephen. "Immortality." In All the Wonder that Would Be: Exploring Past Notions of the Future, Science and Fiction, 265-296. Cham, Springer, 2017. https://doi.org/10.1007/978-3-319-51759-9_10

Wiredu, Kwasi, "Death and the Afterlife in African Culture." In Council for Research in Values and Philosophy. www.crvp.org/book/series02/ii-1/CH7.htm. Accessed on $21^{\text {st }}$ March 2016. . "The Akan Concept of Mind." Ibadan Journal of Humanistic Studies, 3 (1983): 113-134.

."The Concept of Mind with particular reference to Language and Thoughts of the Akans." In Contemporary Philosophy: A New Survey, Vol 5. Dredcht: Martinus Nijhoff Publishers, 1987.

Zenger, Erich and Frevel, Christian. "Die Bücher der Weisheit." In Einleitung in das Alte Testamnent, edited by Christian Frevel. Stuttgart: W. Kohlhammer, 2012. 